\title{
An Editor's Tips on Publishing in Library Literature
}

\author{
Stephen H. Dew
}

\begin{abstract}
Writing for professional library literature can be a challenging experience, especially for new writers and new librarians. This article reviews a variety of how-to-write publications intended for librarians - those books and articles that provide advice and inspiration to aspiring library writers on how to publish in library literature. Applying his experience as a writer and as editor of the Journal of Library \& Information Services in Distance Learning, the author also provides a list of tips on preparing article-length manuscripts to be submitted to library-related journals. When appropriate, special resources and tips are noted for writers working on distance learning subjects.
\end{abstract}

KEYWORDS. Authorship, writing, publishing, research, library literature, distance learning

Stephen H. Dew, MLS, MA, PhD, is Coordinator of Library Services for Distance Education, 100 Main Library, University of Iowa, Iowa City, IA 52242-1420 (E-mail: stephendew@uiowa.edu) 
Writing for professional library literature can be a challenging experience, especially for new writers and new librarians. Fortunately, for authors and potential authors in field of library and information services, there are several useful how-to-write articles and manuals providing guidance through the process of researching, writing, submitting, and publishing a manuscript. The two most recent manuals are The Librarian's Guide to Writing for Publication by Rachel Singer Gordon (2004) and First Have Something to Say: Writing for the Library Profession by Walt Crawford (2003). ${ }^{1}$ Both books provide excellent up-to-date advice and inspirational anecdotes to aspiring authors, and both are packed with details about the process. Crawford, who has a reputation for presenting a humorous slant to things, presents the most entertaining read of the two books. In addition, there are two somewhat-dated manuals (published in the mid-1980s) that nevertheless may provide useful advice for some writers-Librarian in Search of a Publisher: How to Get Published by Brian Alley and Jennifer Cargill and Librarian/Author: A Practical Guide on How to Get Published edited by Betty-Carol Sellen. ${ }^{2}$ Librarian/Author has two chapters that are still relevant — one by Richard Johnston entitled "The Journal Article" and the other, a wonderful piece of advice from Art Plotnik, entitled "Secrets of Writing for the Professional Literature of Librarianship without Losing Your Self-Esteem."”3 Plotnik’s presentation is humorous and lively, and among his intriguing observations, is the following:

Writing is the art of making human communications bearable to humans.

Many people publish because no one can stand listening to them. And little wonder: conversation is rarely backed by research and reflection, and it is never refined through, say, three to four drafts. But in order to publish, people with something to say must go through the cathartic agonies of writing. . . But there 
are limits to what even an author's agonies can yield. The question here is, can library writing be made bearable to librarians? ${ }^{4}$

Plotnik answers his question affirmatively, and he presents witty and informative advice to librarians on how they can become good writers.

In addition to books, there are several journal articles that also provide good advice to beginning library authors. Most recently (2004), Robert Labaree published "Tips for Getting Published in Scholarly Journals" in College \& Research Libraries News. ${ }^{5}$ Among his good advice, Labaree suggests that aspiring authors seek out a new journal for possible submission (something I, as editor of this new journal, can identify with), because a new journal may have a relatively small number of manuscripts under submission and may be more open to working with new authors. Another article that some library writers may find useful is Ruth Carter's 'How to

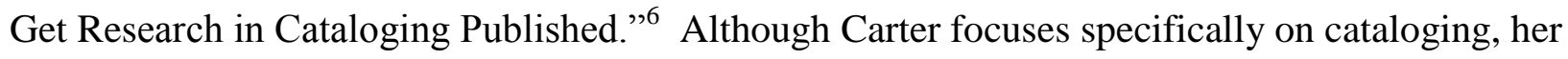
advice ranges to cover information on publishing in the general library literature as well, and she enlivens her discussion with a few good quotations from other sources. For instance, reminding aspiring authors that writing is hard work, she first quotes Samuel Johnson- "What is written without effort is in general read without pleasure,"7 and she follows with a quote from Gene Fowler:

Writing is easy. All you do is stare at a blank sheet of paper until drops of blood form on your forehead. ${ }^{8}$

In addition to the articles by Labaree and Carter, beginning library authors may find additional inspiration and help through such articles as "Getting Published: Surviving in a 'Write Stuff or They Fire You' Environment," “Take Up Thy Pens and Keyboards!: Why It's Never 
Too Late to Think about Publishing," and "How to Be a Successful Scholar: Publish Efficiently."9

If you are new to writing for the professional literature and you want to begin with a relatively small writing project, consider writing an article for a newsletter, especially the newsletter of a professional organization. For North American distance learning librarians, the most relevant newsletter would clearly be the DLS Newsletter published by the Distance Learning Section (DLS) of the Association of College and Research Libraries (ACRL). ${ }^{10}$ Other options for relatively small writing projects would include writing book reviews and reviews of electronic resources. Usually, you can contact the editor of any journal's review section, and s/he will be receptive to working with you. If you are interested in writing book reviews for the Journal of Library \& Information Services in Distance Learning, you should contact Jerilyn Marshall, Book Review Editor, and if you are interested in writing reviews of electronic services, you should contact Paul Pival, the new Editor of "eServices in Libraries."11

If you are interested in writing a scholarly, article-length manuscript, your work will not be easy, but your possibilities are promising-publishing opportunities continue to grow as the number of in-print and online journals increases. Although each journal/publication is managed under its own rules, the most common format for scholarly journals is the peer-reviewed process. The Journal of Library \& Information Services in Distance Learning, for example, is a peerreviewed journal. Most manuscripts are reviewed by two members of the journal's editorial board and the editor. For members of the editorial board, the reviews are anonymous - the copies of manuscripts sent to them never include the identity of the author(s). The reviewers work from a Referee's Checklist created by the editor (see Appendix), but reviewers are not limited to matters only mentioned in the checklist. Reviews usually take a month or more, so 
expect some time to pass before you are notified about the result of the review process. Each reviewer sends the editor comments, suggestions, and a recommendation on whether-to-publishthe-manuscript-or-not, but the editor makes the ultimate decision. Be ready for rejection, and be ready to revise. If a revision is required, follow the suggestions of the editor and reviewers as closely as possible, and re-submit as soon as possible. If rejected, review your document for revision (possibly significant revision) and consider other publications.

Practically every journal now has a Web site, and most provide access to author instructions through the site. ${ }^{12}$ Before submitting a manuscript to any journal, you should read that journal's author instructions carefully. The author instructions include important information about what style manual to use (American Psychological Association (APA), Modern Language Association (MLA), Chicago, etc.), as well as information about manuscript length, margins, fonts, and required personal information. In most cases, especially when you deal with commercial publishers, each author is required to sign a copyright transfer form-if your manuscript is accepted for publication, the publisher of the journal will own the copyright.

Once your manuscript is ready to submit, send it to only one journal at a time. Make sure that the manuscript fits the scope of the journal and follow the author instructions. Upon receipt of your manuscript, the editor should send you a notice about receiving the document. Editors of most peer-reviewed journals keep a log recording the manuscript review process. For The Journal of Library \& Information Services in Distance Learning, for instance, I keep a log that records the date that each manuscript is received, the date and to whom the manuscript is sent for review, the date that the reviewer returns his/her reviewed copy, the date that the author is notified about the reviews and any recommendations (or if necessary, the date that the author is 
notified about rejection), the date that the author resubmits the manuscript, and the date that the author is notified that the manuscript has been accepted for publication.

Once an article has been accepted for publication, the editor usually sends an official letter to the author(s). Be prepared for a long period between an acceptance for publication and the appearance of your article in-print. In many cases, especially for commercial publishers, this delay may be up to six or seven months. Frequently, the full-text of articles will be made available from the journal's Web site before the actual print version is published. In most cases, there are no royalties or financial gains for publishing an article in the library literature; however, for most library-related journals, each author receives one or two copies of the issue in which his/her article is published.

A wide range of good advice can be gained from the literature previously cited in this article. From my experience as an editor and writer, the following are a few brief tips on preparing article-length manuscripts to be submitted to library-related journals:

- Pick a relevant topic that appeals to you and consider journals having a scope that would include your topic. If you are looking for ideas for a topic in the field of distance learning librarianship, Library Services for Distance Learning: The Fourth Bibliography, a Web-based resource edited by Alexander Slade, and recent copies of the Off-Campus Library Services Conference Proceedings should serve you well as beginning points. ${ }^{13}$

- Do the research. Use Library Literature and Information Science Full Text (or its print counterpart, Library Literature and Information Science) and other information resources (such as Slade's online bibliography). ${ }^{14}$ In addition to books and articles, be familiar with other key documents related to your subject. For instance, in distance learning librarianship, all writers should be familiar with the Guidelines for Distance Learning 
Library Services. However, if you are writing about library instruction to distance learning students, you should also be familiar with the Guidelines for Instruction Programs in Academic Libraries and the Information Literacy Competency Standards for Higher Education. ${ }^{15}$ Keep in mind that, depending on your topic, you may also need to search literature outside the field of library and information science. For instance, for this journal, when discussing broad issues and subjects within the field of distance learning, writers should be informed by reading the general distance learning and distance education journals, and research in that field would include a search through such resources as ERIC and EDUCATION FULL-TEXT. ${ }^{16}$ For instance, if you are writing about library instruction to distance learning nursing students, you would, of course, check the library literature for relevant articles, but you would also need to check at least one of the educational resources for articles about instructional and pedagogical practices in distance learning nursing programs, therefore accessing the general distance learning and distance education literature that is not covered in library literature. Find and read the articles, books, and other documents that relate to your topic. As you read any text, take note of important and interesting statements and record them for possible use as direct quotations in your manuscript. Use the information and knowledge gained from your readings: strengthen your manuscript by supporting your discussion with relevant citations and references.

- Organize your presentation in a logical manner. Although there are numerous ways to organize a paper, organizing the manuscript around a basic introduction, body, and conclusion can work well, especially for beginning writers. 
- Try to be a "good writer." Be familiar with the advice of writing manuals such as Strunk and White's The Elements of Style and Art Plotknik's The Elements of Expression. ${ }^{17}$ Keep in mind that good writing is clear and succinct. Use good syntax and word choice.

- Use your computer's spell-checking and grammar functions, but do not depend upon them. Both functions only indicate "possible problems." So, keep in mind that your computer may indicate that there "may" be a problem, when there actually is no problem with the word or phrase that you have used.

- Use a thesaurus and a good dictionary. Word choice is important, and adding variety and precision to your text will help improve its readability.

- Avoid cuteness and informal writing. As a general rule for scholarly writing, do not use contractions (didn't, isn't, I'll, etc.).

- Be consistent in how you use words in your text. If you are going to use an acronym or abbreviation in your text, introduce it to the reader with its full meaning the first time it is used and then be consistent about its use throughout your text. If you are discussing an individual librarian in your text, do so in a consistent manner-for instance, stick with "the pharmacy librarian," and do not use various other identifying terms and phrases like "the pharmacy library liaison," "the library's pharmacy liaison," "the pharmacy library faculty member," etc. Also, be consistent with capitalization. If you capitalize a position's title when you introduce it into your text (Pharmacy Librarian), continue to capitalize that title throughout your text. Be consistent with verb tenses. For instance, in a paragraph discussing another author's work, do not mix present and past tenses. If in the first sentence of a paragraph, you report, "Fred C. Dobbs tells us this," do not in the next sentence state, "Dobbs concluded something else." 
- Be consistent in the way you present numbers. In a paragraph, if you are referring to a survey and you are showing both percentages of respondents and numbers of respondents, be consistent. For instance, give the numbers of respondents first and the percentages in parentheses and be consistent—-seventy-five students (50\%) said this; twenty-five students (16.7\%) said otherwise; forty-five students (30\%) said something else, etc. Do not mix up the way that you present numbers and percentages - seventyfive students $(50 \%)$ said this; 25 students (16.7\%) said otherwise; thirty percent (45 students) said something else, etc.

- Be careful that your pronouns agree with the intended subjects. Do not report, "Any student (singular) can access the library Web site, where they (plural) can find numerous resources." Also, if you are discussing two subjects within a paragraph (librarians and students), be careful how you use the pronoun "they." Readers need to clearly understand whether or not the "they" in your text refers to the librarians, to the students, or to both groups combined.

- Be accurate with quotations - cite the text exactly. When in doubt about how to cite a quotation, be sure to check the proper style manual.

- Have a colleague (or colleagues) read your manuscript for clarity, and make sure that s/he knows that you welcome criticism and suggestions. Be ready for criticism and suggestions. Be ready to do more research (if that is what is suggested), and be ready to revise your text. If a colleague does read your manuscript to help you with your preparations for submission and your manuscript is later accepted, be sure to recognize your colleague in an "acknowledgment" that accompanies the article. Most journals accept, even encourage, such acknowledgements. 
Researching and Writing for publication is hard work. You can find writing advice and inspiration in many places and in many forms, but the final act of writing comes down to the individual putting thoughts and ideas into words. And as Art Plotnik suggests, library authors can make their writing bearable to fellow librarians (and other readers). Seek out writing advice and inspiration where you can find it, but remember that successful writing comes about by persevering in your writing task. Write, rewrite, and rewrite again. There will no doubt be times of frustration, but any frustration can be conquered through perseverance. Your manuscript may take many revisions, but if you stick with the task, the final reward of having published in the professional literature is something that you can certainly be proud of, and it is a permanent record of contribution that will be with you always - nobody can take it away. Being a published writer is a uniquely satisfying experience.

I want to encourage each reader of the Journal of Library \& Information Services in Distance Learning to consider undertaking a writing project, whether a review or newsletter article or whether a more substantial article-length manuscript. I especially urge you to consider writing about your special experience in and knowledge of distance learning library and information services. Write for publication — contribute to our profession and our scholarly discourse. 


\section{APPENDIX \\ Journal of Library \& Information Services in Distance Learning \\ Referee's Checklist}

Each paper should be evaluated on its own merits. The following is a list of suggestions onlythe list is neither inclusive nor exclusive. You should feel free to introduce other criteria when appropriate.

\section{Scope of Journal}

Is the paper related to library and information services in distance learning?

Would the paper be relevant to the readership of the journal?

\section{Content}

If the purpose of the paper is to present information, is it actually informative?

If the paper is based on research, is the research sound?

If the paper is opinion, is it well thought out and persuasive?

If the paper is a review, are the relevant sources considered?

Is the paper accurate, adequately documented, and complete within the author's own terms?

If the paper claims to be "new," is it really new?

Is it an original contribution to the field or a rehash of old information?

\section{Presentation}

Is the paper written in a clear and readable style? 
If the paper still requires work on grammar, spelling, organization, etc., point out examples for the author to consider.

Is the paper well organized? No formal outline is necessary, but there should be a beginning, a middle, and an end, with a logical progression of information and thought.

Technical and professional terminology is fine when appropriate, but is the paper generally free of jargon?

Should the author be asked to add, delete, or change illustrative matter (tables, charts, etc.)?

\section{Value}

Is the paper a useful contribution to the literature?

It does not have to be a landmark article, but it should not be ephemeral or superficial.

Would you publish the article? 


\section{NOTES}

1 Rachel Singer Gordon, The Librarian's Guide to Writing for Publication (Lanham, MD:

Scarecrow Press, 2004); Walt Crawford, First Have Something to Say: Writing for the Library

Profession (Chicago: American Library Association, 2003).

2 Brian Alley and Jennifer Cargill, Librarian in Search of a Publisher: How to Get

Published (Phoenix, AZ: Oryx Press, 1986); Betty-Carol Sellen, ed., Librarian/Author: A

Practical Guide on How to Get Published (New York: Neal-Schuman, 1985).

3 Richard D. Johnston, “The Journal Article,” in Sellen, Librarian/Author, 21-35; Art

Plotnik, "Secrets of Writing for the Professional Literature of Librarianship Without Losing

Your Self-Esteem," in Sellen, Librarian/Author, 79-90.

${ }^{4}$ Plotnik, 79

5 Robert V. Labaree, “Tips for Getting Published in Scholarly Journals," College \&

Research Libraries News 65 (March 2004):137-139.

6 Ruth C. Carter, "How to Get Research in Cataloging Published," Cataloging \&

Classification Quarterly 19 (1994): 107-117.

7 Samuel Johnson, quoted in Carter, 111.

${ }^{8}$ Gene Fowler, quoted in Carter, 111.

9 Ladd Brown, Jeff Bullington, Cindy Hepfer, Wayne Jones, and Robb M. Walter, “Getting Published: Surviving in a 'Write Stuff or They Fire You' Environment (A report of a program at the 2001 North American Serials Interest Group (NASIG) Conference)," The Serials Librarian 42 (2002):13-18 ; Amanda Etches-Johnson, “Take Up Thy Pens and Keyboards!: Why It’s Never Too Late to Think about Publishing," Knowledge Quest 33 (September/October 2004): 42-43; 
Robert Hauptman, "How to Be a Successful Scholar: Publish Efficiently," Journal of Scholarly Publishing 36 (January 2005):115-119.

${ }^{10}$ See the Distance Learning Section (ACRL) Web site, which provides quick and easy access to the DLS Newsletter. Available at: http://caspian.switchinc.org/ distlearn (Accessed January 27, 2005)

${ }^{11}$ Jerilyn Marshall, Head, Reference \& Instructional Services, Rod Library, University of Northern Iowa, 1227 West $27^{\text {th }}$ Street, Cedar Falls, IA 50613-3675 (E-mail:

jerilyn.marshall@uni.edu); Paul R. Pival, Distance Education Librarian, University of Calgary, 213E MLT, Calgary, Alberta, Canada T2N 1N4. (E-mail: ppival@ucalgary.ca).

12 The Web site for the Journal of Library \& Information Services in Distance Learning is available at: http://www.haworthpress.com/web/JLISD/

(Accessed January 27, 2005)

${ }^{13}$ Library Services for Distance Learning: The Fourth Bibliography, edited by Alexander L. Slade. Available at: http://uviclib.uvic.ca/dls/bibliography4.html (Accessed January 27, 2005); Patrick B. Mahoney, ed., Eleventh Off-Campus Library Services Conference Proceedings (Mount Pleasant, MI: Central Michigan University, 2004), later published as Issues 1 and 2 of Journal of Library Administration 41 (2005); Patrick B. Mahoney, ed., The Tenth Off-Campus Library Services Conference Proceedings (Mount Pleasant, MI: Central Michigan University, 2002), later published as Issues 1 and 2 of Journal of Library Administration 37 (2002); Anne Marie Casey, ed., The Ninth Off-Campus Library Services Conference Proceedings (Mount Pleasant, MI: Central Michigan University, 2000), later published as Issues 3 and 4 of Journal of Library Administration 31 (2001). 
14 Library Literature and Information Science Full Text (Bronx, New York: The H.W. Wilson Company, 1984-present); Library Literature and Information Science (Bronx, New York: The H.W. Wilson Company, 1999-present); for material prior to 1999, see Library Literature (Chicago: American Library Association, 1936-1999)

15 “Guidelines for Distance Learning Library Services," College \& Research Libraries News 65 (November 2004): 604-611. Also available at: http://www.ala.org/ala/acrl/acrlstandards/guidelinesdistancelearning.htm (Accessed January 27, 2005)

See also, the Distance Learning Section (ACRL) Web site, which provides quick and easy access to the Guidelines, as well as links to related documents. Available at: http://caspian.switchinc.org/ distlearn (Accessed January 27, 2005)

Guidelines for Instruction Programs in Academic Libraries. Available at: http://www.ala.org/ala/acrl/acrlstandards/guidelinesinstruction.htm (Accessed January 27, 2005). Information Literacy Competency Standards for Higher Education. Available at: http://www.ala.org/ala/acrl/acrlstandards/informationliteracycompetency.htm (Accessed January 27, 2005)

16 ERIC (Washington, DC: United States Department of Education, 1966-present); Education Full-Text (Bronx, New York: The H.W. Wilson Company, 1983-present); Education Index (Bronx, New York: The H.W. Wilson Company, 1929-present) 
17 William Strunk, Jr., and E. B. White, The Elements of Style (New York: Longman, 2000); Arthur Plotknik, The Elements of Expression: Putting Thoughts into Words (New York: Henry Holt, 1996) 